\title{
PHYSIOLOGICAL RESPONSE TO SUN EXPOSURE OF RAMS FED SUGARCANE BAGASSE SILAGE TREATED WITH UREA AND LIVE YEAST CULTURE OR PRONIFER
}

\author{
M. Kobeisy ${ }^{1}$; G. Abd El-Hafez ${ }^{1}$; S. Mousa ${ }^{1}$ and A. Kabak ${ }^{2}$ \\ ${ }^{1}$ Animal Production Department, Faculty of Agriculture, Assiut University, Assiut, Egypt. \\ ${ }^{2}$ Animal Production Department, Faculty of Agriculture, Al-Azhar University, Assiut, Egypt.
}

\section{SUMMARY}

$\mathrm{T}$

This study was conducted on Rahmani rams to investigate the influence of sugarcane bagasse silage treated with urea, live yeast or pronifer on physiological response to sun exposure. Sixteen Rahmani rams with an average body weight of $29 \mathrm{~kg}$ were used in four feeding groups, untreated bagasse, 3\% urea treated bagasse , urea and yeast (10 g per animal daily) treated bagasse and urea and pronifer ( $2 \mathrm{~g}$ per animal daily) treated bagasse. Pronifer is feed additive made by specific lactic acid fermentation of heat-treated soybean meal and malt. Animals were subjected to solar radiation during 3 succession days for $2 \mathrm{hrs}$. from 13:00 to 15.00. Average air temperature and relative humidity during exposure were $40{ }^{\circ} \mathrm{C}$ and $70 \%$, respectively. Respiration rate (RR), pulse rate (PR) and rectal (RT), skin (ST) and wool temperatures (WT) were measured before and after exposure. Blood samples were collected before and after exposure for the determinations of serum total protein, albumin, glucose, urea-N, cholesterol, total bilirubin, AST and ALT. No significant effect of urea, live yeast or pronifer on RT, ST, RR, PR and WT after sun exposure, but the highest value was found in RR for urea group. Also, treatments had no significant effects on serum total protein, albumin and globulin after sun exposure. Glucose is one of the most blood parameters can be affected by exposure to solar radiation, but cholesterol and urea-N were not affected. Animals fed urea had the highest response for serum glucose, ALT and AST during exposure to direct sunlight. In conclusion, using sugarcane bagasse silage with live yeast or pronifer may be useful under sun exposure but urea treatment may be not recommended under sun exposure.

Keywords: Sheep urea, live yeast, pronifer, sun exposure, blood serum.

\section{INTRODUCTION}

A huge quantity of sugarcane bagasse is produced during sugar production. Most of this quantity is using in producing fire and consequently increased air pollution. The palatability of sugarcane bagasse is very low due to its low nitrogen and high fiber content, hence poor digestibility (Khan et al., 1992). It can be used as a low cost roughage source after processing,i.e, preserving it as silage with urea (Abdel-Hafiz et al., 1997). However, high fiber content may increase heat load on animals particularly during heat stress. Abd El_Hafiz (1997) found that lambs fed diet containing roughage and concentrate has significantly higher respiration rate than those fed concentrate mixture only. So, using some supplementation like live yeast and pronifer for bagasse silage treated with urea may support animals against heat stress conditions, the preset experiment was conducted to study the physiological response to heat stress of rams fed sugarcane bagasse treated urea and live yeast or pronifer.

\section{MATERIALS AND METHODS}

The study was carried out on 16 Rahmani lambs over five months old with $29 \mathrm{~kg}$ an average body weight. Sugarcane bagasse was collected and sun-dried for two months then ensiled with 5\% molasses for two months in two treatments, untreated and treated silage, with $3 \%$ urea calculated as dry matter basis. Animals were assigned to 4 groups and receiving $600 \mathrm{~g}$ concentrate diet and one of the following treatments; roughage diet (ad libitum) for 6 months: 1, untreated sugarcane bagasse silage, UBS (control). 2, Urea treated (3\%) SBS (Urea). 3, diet No 2 with live yeast culture, $10 \mathrm{mg} / \mathrm{animal} /$ day (Yeast). 4, diet No 2 with pronifer, $2 \mathrm{mg} / \mathrm{animal} / \mathrm{day}$. Animals were fed once daily and water was offered two times daily for 6 months experimental period. Animals of each dietary group were subjected to exposure to solar radiation during 3 succession days for 2 hours, from 13:00 to 15:00 after feeding trial period. Average 


\section{Kobeisy et al.}

ambient temperature and relative humidity during sun exposure (in June) were $40^{\circ} \mathrm{C}$ and $70 \%$, respectively. Respiration rate (RR), rectal temperature (RT), skin temperature ST), wool temperature (WT) and pulse rate were recorded, immediately before and after exposure to direct sunlight. Respiration rate was measured by counting flank region, rectal temperature by clinical thermometer, skin and wool temperature were measured using telethermometer. Blood samples were taken just before and after exposure to solar radiation for the determination of serum total protein, albumin, glucose, urea $\mathrm{N}$, cholesterol, total bilirubin, AST and ALT concentrations. Blood serum total globulin was obtained by difference between serum total protein and albumin concentrations. .All data were analyzed by ANOVA using General Linear Models Procedure of SAS (1985).

\section{RESULTS AND DISCUSSION}

\section{Physiological problems:}

Results showed that, sun exposure affect significantly on RR, RT, ST, WT and PR for all studied treatments except for rectal temperature in control group and for pulse rate in yeast group (Table 1). Respiration rate is the most one which affected greatly by solar radiation. The highest value for respiration rate was found in urea group after sun exposure (140.5 breath/min.), but its lowest value after sun exposure was found in yeast and followed by pronifer groups which were 129.5 and 131.75 breath/min., respectively. Results may indicated that $3 \%$ urea treated silage can diminish animal's heat tolerance but yeast or pronifer supplementation may improve heat tolerance in sheep. Similar effects of sun exposure were found by Kobeisy (1994) and Shafie et al. (1994). Increasing wool surface temperature with exposing rams to solar radation (Table 1) agreed with Ibrahim (1994) who found increasing wool surface temperature with increasing ambient temperature. Also the increase in pulse rate with exposing rams to solar radation (Table 1) agreed with Pandy and Roy (1969).

Table (1). Effect of sun exposure on some physiological parameters of sheep fed urea treated bagasse with live yeast or pronifer.

\begin{tabular}{|c|c|c|c|c|c|c|c|c|c|}
\hline \multirow[t]{3}{*}{ Item } & \multicolumn{9}{|c|}{ Treatment* } \\
\hline & \multicolumn{2}{|c|}{ Control } & \multicolumn{2}{|c|}{ Urea } & \multicolumn{2}{|c|}{ Yeast } & \multicolumn{2}{|c|}{ Pronifer } & \multirow[t]{2}{*}{$\mathrm{SE}$} \\
\hline & $\mathrm{B} * *$ & $\mathrm{~A}$ & B & $\mathrm{A}$ & B & $\mathrm{A}$ & B & $\mathrm{A}$ & \\
\hline $\begin{array}{l}\text { Respiration, } \\
\text { breath/min. }\end{array}$ & $40.00^{\mathrm{b}}$ & $132.00^{\mathrm{a}}$ & $41.00^{\mathrm{b}}$ & $140.50^{\mathrm{a}}$ & $40.00^{\mathrm{b}}$ & $129.50^{\mathrm{a}}$ & $40.50^{\mathrm{b}}$ & $131.75^{\mathrm{a}}$ & 3.40 \\
\hline $\begin{array}{l}\text { Rectal temp., } \\
{ }^{\circ} \mathrm{C}\end{array}$ & $39.43^{\mathrm{b}}$ & $40.45^{\mathrm{ab}}$ & $39.48^{\mathrm{b}}$ & $41.00^{\mathrm{a}}$ & $39.53^{\mathrm{b}}$ & $41.48^{\mathrm{a}}$ & $39.48^{b}$ & $41.23^{\mathrm{a}}$ & 0.04 \\
\hline Skin temp., ${ }^{\circ} \mathrm{C}$ & $38.55^{\mathrm{b}}$ & $40.78^{\mathrm{a}}$ & $38.15^{\mathrm{b}}$ & $41.50^{\mathrm{a}}$ & $38.60^{\mathrm{b}}$ & $40.98^{\mathrm{a}}$ & $38.15^{\mathrm{b}}$ & $41.15^{\mathrm{a}}$ & 0.68 \\
\hline $\begin{array}{l}\text { Wool temp., } \\
{ }^{\circ} \mathrm{C}\end{array}$ & $35.55^{\mathrm{c}}$ & $39.90^{\mathrm{b}}$ & $35.85^{\mathrm{c}}$ & $42.00^{\mathrm{a}}$ & $35.95^{\mathrm{c}}$ & $42.30^{\mathrm{a}}$ & $35.83^{c}$ & $41.55^{\mathrm{a}}$ & 0.52 \\
\hline $\begin{array}{l}\text { Pulse rate, } \\
\text { beat/min. }\end{array}$ & $75.50^{\mathrm{bcd}}$ & $85.50^{\mathrm{a}}$ & $70.00^{\mathrm{d}}$ & $81.50^{\mathrm{ab}}$ & $79.50^{\mathrm{abc}}$ & $80.50^{\mathrm{abc}}$ & $74.50^{\mathrm{cd}}$ & $85.50^{\mathrm{a}}$ & 1.82 \\
\hline
\end{tabular}

\section{Some blood serum constituents:}

In general, total protein, albumin and globulin were not significantly affected by solar radiation (Table 2). Similar results were found by Shoukry (1981) and Kobeisy et al. (2001). However, dietary treatment showed that, urea group had the highest value of serum protein among dietary groups; such increase was mainly due to high serum globulin. On the other hand, serum albumin was adversely affected by urea supplementation and to some extent in animals receiving urea plus live yeast or pronifer.

Results showed that, glucose and may be serum ALT and AST were the most blood parameters that affected significantly by exposure to solar radiation, but cholesterol, urea-N and bilirubin were not affected by exposure to solar radiation (Table 2). Also, difference between before and after sun exposureon urea-treated animals had the highest serum glucose, ALT and AST indicating the highest response to heat stress. The increase of serum glucose may be due to increasing secretions of adrenalin and cortisol as a physiological response to heat stress (Seed, 1992), or due to more glucose consumption for urea assimilation in sheep body before exposure to heat stress. Live yeast or pronifer supplementation 
can enhance serum glucose before sun exposure and diminish the difference. However the increase of serum ALT and AST after exposure to solar radation indicating lowest tolearance to heat stress of urea treated group and such result may be due to increase cardiac activity and output as a result of sun exposure (Khali and Abd-Elhakim, 1990). Similarly, Kobeisy et al. (1994) and Kobeisy et al. (2001) found an increase of serum AST and ALT in animals exposed to solar radiation.

In conclusion: Sun exposure have adverse effect on respiration rate and rectal temperature and some blood parameters particularly, serum glucose, AST and ALT enzymes, particularly in animals fed 3\% urea. However addition of live yeast (10g/animal and day) or pronifer ( $2 \mathrm{~g} /$ animal and day) may be useful for animals feeding urea and exposed to sun exposure.

Table (2). Effect of sun exposure on some blood serum constituents of sheep fed urea treated bagasse with live yeast or pronifer.

\begin{tabular}{|c|c|c|c|c|c|c|c|c|c|}
\hline \multirow[t]{3}{*}{ Item } & \multicolumn{9}{|c|}{ Treatment* } \\
\hline & \multicolumn{2}{|c|}{ Control } & \multicolumn{2}{|c|}{ Urea } & \multicolumn{2}{|c|}{ Yeast } & \multicolumn{2}{|c|}{ Pronifer } & SE \\
\hline & B** & A & B & A & B & A & B & A & \\
\hline Total protein, $\mathrm{g} / \mathrm{dl}$ & $7.18^{\mathrm{b}}$ & $7.28^{\mathrm{b}}$ & $7.65^{\mathrm{a}}$ & $7.73^{\mathrm{a}}$ & $7.38^{\mathrm{b}}$ & $7.33^{\mathrm{b}}$ & $7.30^{\mathrm{b}}$ & $7.40^{\mathrm{b}}$ & 0.07 \\
\hline & $93^{\mathrm{a}}$ & $2.98^{\mathrm{a}}$ & $2.53^{\mathrm{d}}$ & $2.58^{\mathrm{d}}$ & $2.71^{\mathrm{c}}$ & $2.80^{\mathrm{b}}$ & $2.72^{\mathrm{c}}$ & $2.77^{\mathrm{bc}}$ & 0.02 \\
\hline Globu & $4.24^{\mathrm{d}}$ & $4.30^{\mathrm{cd}}$ & $5.12^{\mathrm{a}}$ & $5.14^{\mathrm{a}}$ & $4.67^{b}$ & $4.53^{\mathrm{bc}}$ & $4.58^{\mathrm{b}}$ & $4.63^{\mathrm{b}}$ & 0.08 \\
\hline Glucose, $\mathrm{mg} / \mathrm{dl}$ & $73.86^{\mathrm{ab}}$ & $75.36^{\mathrm{a}}$ & $52.25^{\mathrm{d}}$ & $63.08^{c}$ & $62.33^{\mathrm{c}}$ & $70.13^{\mathrm{ab}}$ & $66.80^{\mathrm{bc}}$ & $72.03^{\mathrm{ab}}$ & 2.12 \\
\hline & $64.30^{\mathrm{b}}$ & $62.53^{\mathrm{b}}$ & 80.9 & & & & $77.20^{\mathrm{a}}$ & & 2.16 \\
\hline Urea & $9.99^{\mathrm{b}}$ & $9.74^{\mathrm{b}}$ & $20.00^{\mathrm{a}}$ & $19.50^{\mathrm{a}}$ & $19.50^{\mathrm{a}}$ & 19.2 & $19.20^{\mathrm{a}}$ & $19.23^{\mathrm{a}}$ & 0.23 \\
\hline T. Bilirubin, $\mathrm{mg} / \mathrm{dl}$ & $0.29^{c}$ & $0.29^{c}$ & $0.50^{\mathrm{a}}$ & $0.50^{\mathrm{a}}$ & $0.36^{\mathrm{b}}$ & $0.39^{\mathrm{b}}$ & $0.36^{\mathrm{b}}$ & $0.38^{\mathrm{b}}$ & 0.02 \\
\hline ALT, U/l & $11.00^{\mathrm{d}}$ & $17.75^{\mathrm{c}}$ & $17.50^{c}$ & $29.00^{\mathrm{a}}$ & $16.50^{c}$ & $26.25^{\mathrm{b}}$ & $17.25^{\mathrm{c}}$ & $28.00^{\mathrm{b}}$ & 0.73 \\
\hline AST, U/l & $16.25^{\mathrm{c}}$ & $28.25^{\mathrm{d}}$ & $31.75^{\mathrm{c}}$ & $44.75^{\mathrm{a}}$ & $30.25^{\mathrm{cd}}$ & $42.00^{\mathrm{a}}$ & $31.75^{\mathrm{c}}$ & $38.50^{\mathrm{b}}$ & 1.08 \\
\hline
\end{tabular}

*Values are least square means (LSM) and SE is a standard error of LSM. Control, sugarcane bagasse silage (SBS); Urea, SBS+3\% urea; Yeast, SBS+3\%urea+10 gm yeast lanimal and day and Pronifer, SBS + 3\% urea + $2 \mathrm{gm}$ pronifer /animal and day. Means within rows differ $(P<0.05)$ when superscripts differ.

**Animals exposed to direct sun light for two hours, $B=$ before exposure and $A=$ after exposure

\section{REFERENCES}

Abd-El-Hafez, G.A.; H. A. Daghash and M. A. Kobeisy (1997). Growth performance and some blood constituents in sheep fed sugarcane tops or bagasse treated with urea. Egyptian J. Nutr. And Feeds. Proceeding of the 6 th Conference on Anim. Nutr., 17-19 Nov., pp: 161.

Ibrahim, S.F. (1994). Effect of crossing Romanove with Rahmani sheep on some physiological and reproductive performance. M.Sc. Thesis., Fac., Agric., Al-Azhar Uni., Cairo, Egypt.

Khalil, M.H. and N.F. Abd-El-Hakim (1990). Some physiological responses to heat stress, dehydration and starvation in lohman selected longhorn cockerels. Egypt. J. Anim. Prod., 27:37.

Khan, M.E.; A. Ali and Z.O. Muller (1992). Nutritional evaluation of sugarcane bagasse based rations treated with urea and cattle manure. Anim. Feed Sci.Technol., 38:135.

Kobeisy, M.A. (1994). Effect of exposure to solar radiation on some physiological and hematological parameters in suckling Jersy calves fed ascorbic acid. Vet. Med., J., 42:285.

Kobeisy, M.A.; G.A. Abdel-Hafez; F.F. El-Hommosi and H.S. Badawy (2001). Influence of solar radiation and feeding level on feed and water intakes, digestibility, thermo-respiratory response and some blood constituents in sheep. $6^{\text {th }}$ Sci. Cong.,Egypt. Soc., for Cattle Deseases. Pp: 306, Assiut, Egypt.

Pandy, M.D. and A. Roy (1969). Variation in cardio-respiratory rates, rectal temperature, blood haematocrit and hemoglobin as measures of adaptability in buffaloes. Br. Vet. J., 125:463.

SAS (1985). SAS User's Guide: Statistics. SAS Int., Cary, NC.

Seed, E.W. (1992). Stress management in poultry, particularly under hot climatic conditions. Rovigypt Poultry Seminar. Pp: 63-100.

Shafie, M.M.; H.M. Murad, T.M. El-Bedawy and S.M. Salem (1994). Effect of heat stress on feed intake, rumen fermentation and water turnover in relation to heat tolerance response by sheep. Egyptian J. Anim. Prod., 31:317.

Shoukry, H.M. (1981). Adaptability of some local and foreign breeds of sheep under Egyptian environment. M.Sc. Thesis., Fac. Agric. Al-Azhar Univ., Cairo, Egypt. 
الاستجابه الفسيولوجيه للتعرض للشمس للخراف المغذاه على سيلاج مصاصه القصب والمعامله باليوريا وخميرة البيره الحيه او البرونوفير.

\author{
مصطفى قبيصى1، جلال عبد الحافظ1، سليمان مصيلحى1و احمد كبكة

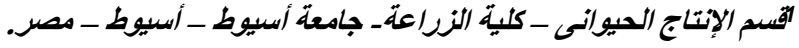 \\ مقسم الإنتاج الحيوانى - كلية الزراعة- جامعة الأزهر - أسيوط - مصر.
}

\begin{abstract}
كانت الدراسه بغرض بحث تاثير سيلاج مصاصه القصب المعامل باليوريا والخميره او البرونوفير على الاستجابه الفسيولوجيه

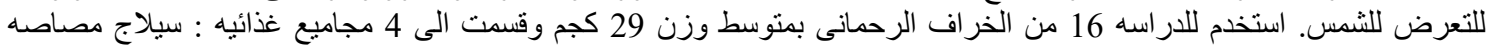

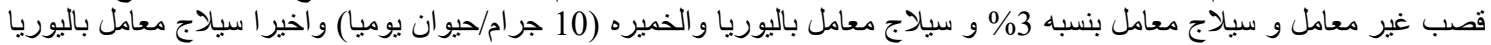

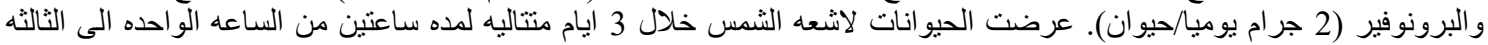

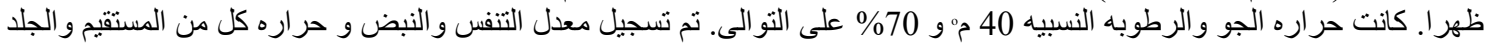

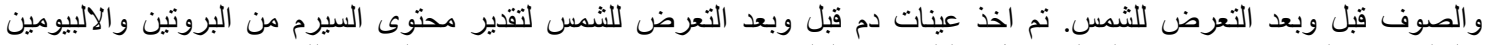

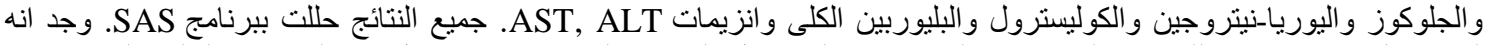

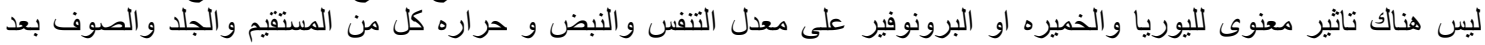

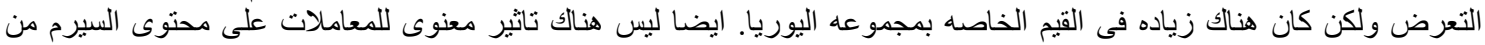

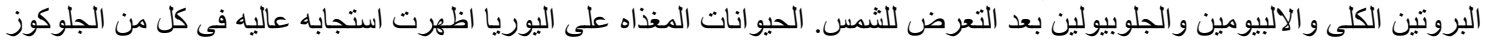

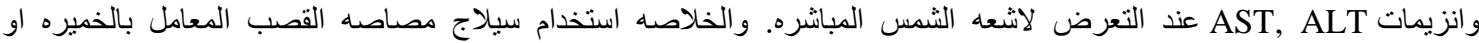
البرونوفير ربما يكون مفيد عند تعرض الحيو انات للثمس ولكن قد لا ينصح بالمعامله باليوريا تحت ظروف التحات التعرض للثمس.
\end{abstract}

